\title{
The Wretched on the Walls: A Fanonian Reading of a Revolutionary Albanian Orphanage
}

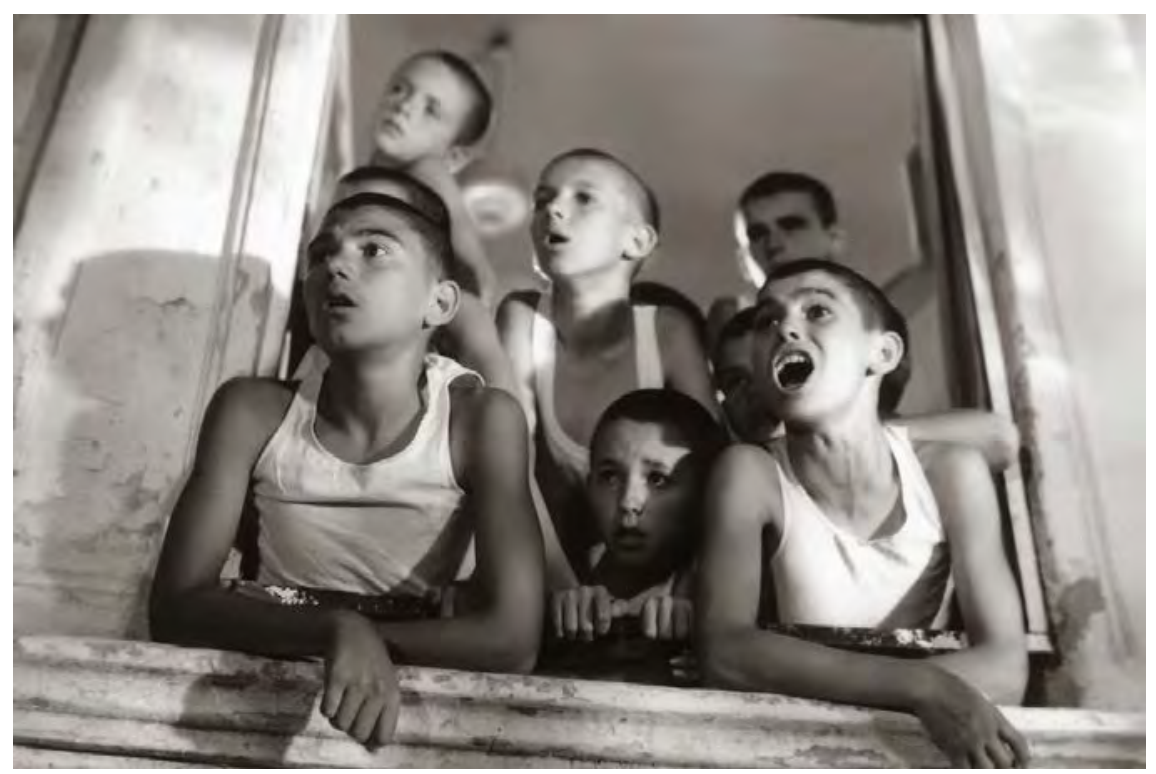

\section{Abstract}

Using Franz Fanon's “On Violence," this paper analyzes dynamics of power and violence in Lulëkuqet mbi Mure / Red Poppies on Walls, a 1976 Albanian film about WWII anti-fascist resistance, told through the story of a group of orphans in Italian-occupied Albania. Fanon's explication that the colonizer's power is founded on force and maintained through violence, capitalist exploitation, dehumanization and compartmentalization, elucidates the film. His argument that decolonization is possible only through greater counterviolence is critical in understanding why the orphans use violent means to liberate themselves. The children's struggle against the fascist orphanage directors is noticed and harnessed Communist Party members. I argue that

Photo: Still from "Lulëkuqet mbi Mure" (1976); used with permission of the Albanian Central State Film Archive / Arkivi Qëndror Shtetëror i Filmit

(C) Genta Nishku 2020

(C) Feminist Critique: East European Journal of Feminist and Queer Studies 2020, № 3, p. 39-63;

http://feminist.krytyka.com (ISSN 2524-2733) 
though the Party's guidance helps the children fight their subjugation, it also curbs their revolutionary potential. Thus, the didactic and propagandistic goals of Lulëkuqet mbi Mure allow only for a strict cold war dichotomy: one is either a fascist, capitalist and colonizer, or a communist, revolted colonized subject ready to take up arms. My engagement with the film, however, demonstrates that the children's solidarity with one another and their subtle resistance prior to the communists' intervention, gestured toward an alternative way of building community - one closer to Fanon's ideas of a new humanism, even if it ultimately remains unrealized in the film.

Keywords: Albania, Fanon, decolonization, violence, resistance.

$\tau$ t is nighttime. Sulo has been shot. His small body falls from the top of the orphanage wall he had been climbing in his attempt to flee. The blow is fatal. The Italian fascist night patrol has mistaken Sulo for an intruder trying to break into the building and shot him. Sulo's friends, the other children of the orphanage, hear the shot and slowly move toward the window. They had been barricading their door with furniture to keep out the orphanage's caretaker. The caretaker, indignant at the trick the children had played on him earlier, which had caused him to fall down the stairs and break an arm, had been on a mission to find the culprit among them. He had targeted Sulo, a sensitive and quiet boy, to become his spy and expose the guilty ones. Every day since the accident, the caretaker tried new forms of manipulation on Sulo: teaching the boy what statements to make to provoke a confession, bribing him with food while the rest of the children were being starved, and finally confronting him in the late night hours. Sulo, tormented by the very thought of betraying his peers, spends the night sobbing. Once the other boys learn of his predicament, they try to devise strategies for Sulo to avoid the caretaker and his next investigation. The night of Sulo's death, they know the caretaker expects him to reveal the names of the guilty children, so they advise him to stay put and use the excuse of having fallen asleep as an explanation. But the caretaker does not accept this excuse, gets furious at Sulo's insolence and begins to beat him, threatening to break his neck. Sulo's attempt to flee the caretaker's ire lands him outside the orphanage walls, where he is spotted by the patrol and shot.

The children's efforts had aimed to resist the caretaker's demands, which they knew would result in violent beatings, and even worse, in the betrayal of the solidarity they share among each other as orphans in Streha Vorfnore. A public orphanage in Tirana operated by a pro-fascist administration under the tutelage of King Zogu, the institution served as an incubator for the promotion of Mussolini's ideology during the Italian occupation of Albania. In the now canonical essay "On Violence" in The Wretched of the Earth, Frantz Fanon describes the colonized subject's dreams as action-filled ones where they first release the "aggressive vitality" collected within their bodies as a result of the violence, dehumanization and compartmentalization of the co- 
lonial world (Fanon 2004, 15). The colonized experience freedom through dreams of a radical reversal of roles, the complete reorganization of society, in which the colonized take the colonizer's place. It is not by chance, then, that much of the action of the Albanian film Lulëkuqet mbi Mure / Red Poppies on Walls occurs at night and in the children's sleeping quarters, where they are packed one on top of the other in shabby bunk beds. However decrepit and crowded this room may be, it serves as the children's only space away from the surveillance of orphanage administration. In this paper, I will conduct an analysis of Lulëkuqet mbi Mure through the lens of Fanon's "On Violence." The analysis reveals how this film, directed by Dhimitër Anagnosti and released in 1976, closely mirrors the violence and dehumanization of colonialization described by Fanon. Critical to understanding this film is Fanon's argument that only a counterviolence of greater magnitude than that of the colonizers' whom as he shows, establish their power through force and maintain it thanks to violence, capitalist exploitation, dehumanization and compartmentalization - can make decolonization possible. Ultimately, it is through such a strategy of counterviolence that Lulëkuqet mbi Mure's oppressed orphans liberate themselves from the subjugation, dehumanization, beatings and abuse of the fascists in charge of the institution. While the children had created their own small ways of resisting, it is the guidance of communist insurgents that instructs them on how to make strategic use of violence against their oppressors. Through this guidance, the children's greater revolutionary potential is curbed in order for them to join the Communist Party, and thus be part of another ideological system.

I view the children's marginal and ambiguous position as orphans - who lack traditional family figures that can steer them toward the right set of values, and who can be more easily exploited - as what makes them particularly vulnerable targets of ideological training from both the communist and fascist factions of the film. The Italian colonists and their allies in the national bourgeoisie, to use Fanon's term, either question or fully reject the children's humanity, and subject them to great violence. At the same time, they need the orphans to populate the orphanage so they can profit by stealing from its funds, as well as from the rhetoric of "civilizing" the children. On the other hand, the Albanian communists or the "revolutionaries from the towns" to use another of Fanon's terms, recognize in the children's suffering the potential for indoctrinating them into the Communist Party and making them take up arms for national liberation. Yet they also fear that if the children's rage goes unregulated it could disturb the Party's careful planning, thus they need to control the children's thoughts and actions. Although the orphans manage to create some forms of anti-fascist resistance and solidarity prior to being officially incorporated into the national liberation struggle, the film does not allow for these modes to develop fully. Instead, it divides the world into two clearly delineated sides, from which the children must choose: will they side with the fascist, colonist capitalists or will they join the communist nationalists? 
That Lulëkuqet mbi Mure poses this question is no surprise, considering it was made by the propaganda machine that the Party of Labor of Albania ${ }^{1}$ had developed to solidify a national identity as dichotomously opposite to the colonial and imperial powers of the West. Nonetheless, its depiction of Albania under Italian occupation does provide an opportunity to think about colonialism and decolonial struggle in the context of the Balkans, a region that occupies an ambiguous place within both de- and post-colonial studies. Fanon serves as a crucial interlocutor here, as his writing on decolonial struggles during the cold war provides apt tools for interpreting both the film's potential for critique of inequality and its limits in making such a critique, given its conditions of production. What we find in Lulëkuqet mbi Mure is a world that exemplifies the compartmentalization named by Fanon as a key cause of colonialism's dehumanizing violence. In Fanon's analysis, society is divided into clearly demarcated quarters that are stratified primarily by a racial division where white colonizers are the ruling class and black natives dwell in the lowest ranks. The compartmentalization of the colonial world manifests in spatial segregation, which dictates those colonized will live in the worst possible state, while the colonizers live in the best (Fanon 2004, 4). Colonial compartmentalization also divides the colonial world in terms of morals and culture, thus creating a Manichean world where colonizers represent goodness and the colonized represent pure evil (McLaughlin 2014, 111). The result of such compartmentalization of the world at the spatial, racial, sociocultural and moral level is the complete dehumanization of the colonized an effective strategy in order to justify exploitation of people and resources in the colonized territory. Thus, both the world in the film and the colonial world are ones already poised toward violence because their very foundations are constructed out of violence. The only response to such a system and the only way to ensure the goal of decolonization - the "substitution of one 'species' of mankind by another" - is a violent upheaval that does more than just replace who is in power, but collapses the entire system (Fanon 2004, 1). Fanon's thought on decolonization and his particular concern with the workings of violence within this process, combined with his attention to psychosocial effects experienced by colonized subjects and his use of a Marxist analysis, make him a pertinent interlocutor for a film depicting a national liberation struggle led by communist rebels, during the precise moment when society's most marginalized must make a choice about whether to take up arms.

In Lulëkuqet mbi Mure, it is Sulo's death that persuades the orphans of the necessity for counterviolence. After Sulo dies, they abandon their other methods of resistance to join the militant armed struggle. The children understand that Sulo's death was the expected result of a colonial, imperialist and capitalist world that seeks the ultimate exploitation of the people rele-

${ }^{1}$ The Communist Party of Albania was established in 1941. In 1948 it changed its name to the Party of Labor of Albania. 
gated to the bottom. Having been well acquainted with violence through their experiences in the orphanage, the children are now faced even more clearly with the most concrete and painful proof that their lives are disposable, not their own, and that they are not free. This knowledge does not defeat them, however - it is after Sulo's death that the children begin to rebel even more against the fascists in charge. When the orphanage's director gathers them to spin lies that blame the caretaker for Sulo's death, which he proclaims a tragedy because Sulo was a nice child who could have become a dignified fascist citizen, one of the children shouts, "we heard the shots!" Later, they also refuse to sing the Italian songs they are being taught, saying that they have no use for them and go further, openly shouting, "death to fascism!" Their anger and rebelliousness are recognized by Ali, a secret communist from the city and a friend of the film's protagonist who is also one of the boys of the orphanage, Jaçe. Their literature teacher is another secret communist who inspires and instructs the children. Right after Sulo's death, the teacher recites Fan Noli's elegiac and patriotic poem "Anës Lumenjve" / "Next to the Rivers." His passion ignites the children's spirits, some of whom spend the night writing anti-fascist messages on the walls. When the director banishes these children from the orphanage, they join their literature teacher and Ali in the quarters of the Communist Party. The teacher initiates them into the Party, telling them it will now be their "new mother".

This mother has a task for them, and it is a violent one: "the annihilation of a dangerous agent". In the final scenes of the film, the children coordinate with one of the communist insurgents to shoot and kill the orphanage's director. It is the third and last shooting in the film, and it is through this act that the children are redeemed. The murder of the director is the "irreversible act" that all militants must perform in order to join the insurgency group (Fanon $2004,44)$. Fanon provides the case of the Algerian struggle for independence, where one could only join the ranks of the militants by earning their trust through an act that would make it impossible to re-enter the colonial system ever again (Fanon 2004, 44). Similarly, the children gain a place within the quarters of the Communist Party only through the commitment that they will assist with the director's murder. As viewers, we are meant to believe that this inclusion into a different ideological system brings the children joy, comfort and freedom. In the film's closing scene, we see Jaçe biking through the city after fleeing from the shooting that kills the orphanage director. He now wears a hat and a checkered button-down shirt, symbols of his new identity, though we never learn if the new system that granted Jaçe his new identity reproduces imbalances of power that continue to harm marginal members of society, or if the decolonial struggle is successful in achieving what Fanon calls a new, more equitable humanism. I argue that while there may be no definite answer to be found within the film, especially in light of the didactic purpose it serves, paying close attention to the children - these poppies that hang onto the wall, who watch the outside world with hope and conviction, who create small ave- 
nues of their own resistance while under pressure to conform to one ideology, whose flowing blood colors the walls red but who ultimately do not move any of the adults in the film toward the real "redistribution of wealth" and resources advocated by Fanon - can give us critical insights into the workings of ideology, categorization, and compartmentalization under colonialism.

\section{Colonialism and capitalism in the orphanage}

Lulëkuqet mbi Mure takes place during Mussolini's occupation of Albania, which made the country part of the Italian Empire from 1939 until 1943. Mussolini exerted his influence on Albania with the support of Ahmet Zogu, Albania's self-proclaimed king, who placed the country under a decade long authoritative rule (Juka 2012, 8-10). Since Zogu refused some of Mussolini's demands, the latter gave Albania an ultimatum and went forth with Italy's plans for invading the country. These plans were in line with the Italian state's imperialist and expansionist aims that included annexation of Tripolitania and Cyrenaica, territories in Libya (Hom 2012, 282). Thus, Italy's influence and interests in Albania had deep roots that were characterized by a colonial mentality and strategy. We can see this reflected in Italy's rhetoric around Albania's "racial" and "cultural" make-up, which they saw more closely affiliated with that of Italy than the Slavic "character" of Yugoslavia (Kallis 2000, 133). Aristotle Kallis explains that this rhetoric was found in many reports published in Italy at the time, which served to bolster support for the invasion of Albania, whose strategic geopolitical location would make it an effective Italian-controlled outpost between Yugoslavia and Greece, eventually leading to further expansion into the Balkans. That the racial and cultural make-up of the colony was described in these terms of affinity allows us to glean important insight into Lulëkuqet mbi Mure, whose plotline centers around the moment when communist partisan groups were rebelling against the fascist occupation of the country. It was not uncommon to see this kind of logic used in regard to the Balkans, which as Maria Todorova argues, has been constructed in the western imaginary "not as other but as incomplete self" (Todorova, 2010 , 18). Rather than being a complete other, like colonies further east, the Balkans were seen as a version of the self that was not yet civilized, but stuck in a backward, pre-modern temporality. This explains the need for the region to be civilized by benefactors from across the Adriatic, whom we see parading inside the orphanage of Lulëkuqet mbi Mure, preaching about the lofty cultural values of fascist civilization, which the orphans still need to learn.

Similar to the ambiguity that the geopolitical territory of Albania (and the Balkans more generally) occupies, the orphanage where the children live is also in a position of liminality within the colonial system. We learn early in the film that the all-boys orphanage is located in Tirana and administrated by King Zogu's government during the Italian occupation. The institution is directed and operated by a group of local pro-fascist employees: a director, a caretaker, and an accountant. The latter two oversee the daily operations of the orphanage, including meals and lessons, which are provided by other 
local employees. Both the caretaker and the accountant are convinced that Italy's presence in the country will help Albania, and they have no qualms about mistreating the orphans so that they learn to follow fascism. In this, they follow the orphanage's director, who leads the institution with an iron hand and little regard for the children. He works to ensure the orphans' ideological allegiance to fascism, even giving them lessons in the Italian language. What makes the director even more despicable is that he steals government funds allocated for the orphans, deliberately depriving them of clothing and food so he can pass the money to the Italians. The director acts in accordance with Fanon's depiction of the "colonialist bourgeoisie" - the elite class of the colonized country who have learned they can gain economic advantages by following the colonizers' orders and who thus have convinced themselves they benefit from colonialization (Fanon 2004, 22-3, 28).

Given that the orphanage offers substantial financial benefits and political leverage for the director, he cannot fully reject its value, and in turn, the value of the orphans. He despises the children but at the same time, boasts of the accolades the orphanage earned from representatives of the kingdom, and stresses their need for education on both fascist ideology and Italian culture and language. In a back and forth with the secret communist Ali, the director disagrees with the man's assertion that the orphans are "just children". When Ali arrives to pick up his friend Jaçe for a day out in the city, the director explains to him that the administration sees the orphans as "the future of Albania." This explains why he is hard at work cultivating the children "spiritually and physically" in service of fascist values and against troubling ideas of communism that have infected the city. The director understands that the economic gain from interfering with the operations of the orphanage, while at the same time purporting a cultivation of "values", is effective for earning him some power in the colonial system. As Fanon argues, there is no greater threat to such a profitable dynamic than "socialist propaganda [which] might infiltrate the masses and contaminate them," by convincing them that they are undeserving of the inferior status ascribed to them by their occupiers (39). ${ }^{2}$

The mutual interdependence of colonial and capitalist systems explains why the colonizers and their allies among the colonized population are concerned with preserving the status quo without resorting to absolute violence. If armed resistance from the colonized side were to start, and if the colonists were to respond through violent large-scale repression, then the economic investments made by the colonists would be in jeopardy. At the first signs of trouble during the decolonization process, "[the] monopolistic fraction of the metropolitan bourgeoisie will not support a government whose policy

\footnotetext{
${ }^{2}$ Albanian theorist Gani Bobi further supports this observation, writing that in the context of Albania between the two world wars, the consequences of the Ottoman colonial rule manifested in internal tensions and trauma. This is especially evident in the elite classes, who come to realize the precarity of their rule and thus form arguments about why Albania should not be self-governed (Bobi 43-44).
} 
is based solely on the power of arms" because what they "expect is not the devastation of the colonial population but the protection of their 'legitimate interests' using economic agreements" (Fanon 2004, 27). A purely violent response to the colonies would lead to such "devastation" thereby making economic profit impossible. This is why, in Lulëkuqet mbi Mure, the orphanage director and his fascist superiors are not indifferent to the news of Sulo's death, even if they do not care about his life. They become agitated because of what this murder would sound like in the press. How does the orphanage look when the institution allows one of the children to be shot by the Italian night guard? Sulo's death too explicitly connects colonialism to deadly violence. Not only does the boy's murder compromise the orphanage's status, but it also has the potential of igniting rage among the population and bringing them to the communists' side. The director and his fascist supervisor know that news of Sulo's death at the hands of the night patrol would risk ending the steady supply of money they receive from the orphanage. Thus, they attempt to cover up the truth and concoct a fictitious story that places the blame for the child's death on the caretaker's ire, completely erasing the involvement of the fascist night patrol.

The film's exposure of the underlying capitalist interests of the colonizers and their allies relates to its production from the Kinostudio "Shqipëria e Re" (New Albania), the national and only film studio in Albania during the country's five decades of socialism. The Kinostudio played an integral role in constructing Albania's national identity after WWII. In a country with high rates of illiteracy, films were better able to reach urban and rural populations with the official narrative of the new, socialist Albanian identity - which was ensured through support and resources from the film industries of the Soviet Union, and later China (Mëhilli 2018, 612). Albanian filmmakers were restricted to producing films with clear ideological purposes, where the didactic teaching of lessons from the Party took precedence over the aesthetic and artistic inclinations of the director. The Party placed the Kinostudio under a highly regulated system of monitoring and censorship: all directors, screenwriters, cinematographers, cameramen, and editors were under the leadership of an "artistic director" appointed by the Party, while the Ministry of Culture decided on the thematic line that all directors and writers had to adhere to for the year (Williams 2012, 226). The latter part of the 1970s coincided with an increase in the Party's isolationist policies in all areas of Albanian political, economic, and social life. In regard to filmmaking, this meant greater censorship, greater control of film production, and more emphasis on film's ideological purposes (Gjikaj and Puto 16). Released in 1976 and directed by Dhimitër Anagnosti, one of the most well-known and prolific directors of the socialist period, Lulëkuqet mbi Mure can only be properly understood through the background of its production, where Albanian filmmaking during socialism was at the crossroads of cold war politics. 


\section{The colonial world through the spacial politics of the orphanage}

Lulëkuqe mbi Mure opens with a shot of the orphanage wall. Children are seen hanging on it, watching the happenings in the city outside the confines of the orphanage. The focus on the orphanage's walls sets up a key dynamic of the film: similar to the colonial world described by Fanon, this is also a world of separations and compartments. The orphans are relegated to the space behind the wall, where their world is comprised of a small yard, a classroom, their communal bedroom full of bunkbeds, and the dining room where they sit in identical rows of tables, hoping to receive some food. In Fanon's description of the colonial world as one of compartmentalization, the first apparent division is the spatial separation of colonized from colonizer, which coincides with racial, social, and class hierarchies. The colonizer lives in a sector made of resilient stone and steel, full of light and paved roads, where everything is clean and orderly. Like the colonist himself, this sector is the "extension" of the metropolis (Fanon 2004, 15). The sector of the "natives" is the direct opposite: it is a space of malnourished people and dilapidated infrastructure, where resources are scarce and misery, violence, and humiliation reign. Understanding well that their own position is one of inferiority and exploitation, the colonized subject refuses to accept this inferiority any longer. During the decolonization process, the colonized are driven by an impulse to take the position occupied by the colonist and radically alter their reality (Fanon 2004, $2-3$; 17). Embedded in the process of decolonization, then, is the drive to destroy this compartmentalization, the colonists' sector and all those living in it. It is through this process that the colonized subject, dehumanized through colonialization, becomes human again, part of "a new generation of men, with a new language and a new humanity" (Fanon 2004, 2). Thus, the rediscovery of one's humanity is a prerequisite for undertaking the decolonial struggle.

In Lulëkuqet mbi Mure, we do not see the colonizer's sector, and we only have glimpses into the space outside of the orphanage. Instead, most of the film is concentrated within this institution, which as was mentioned earlier, occupies an ambiguous geo-political position - meaning that it is not fully the compartment of the colonized, which is due to something I discuss below, namely the orphans' own ambiguous status in terms of "humanity". While the process of constructing the orphans as subhuman is well underway, it is not cemented completely, as the children are still considered trainable in the "civilized" ideology of their fascist occupiers. Even though it is certainly part of the sector of the colonized, the orphanage's role in educating the next generation of followers of fascism gives it a unique status. This makes the orphanage a place where there can be more mixing between social strata. In a way, the separated compartments of colonized and colonizers find a "meeting" location within the orphanage: the wealthy families from the city who offer the orphans "charity" by taking them home for a meal, the refined music teacher 
who crosses the orphanage gate each day to teach the children Italian songs, the visit from Zogu's officials that the director mentions to Ali, all point to the complex position of the orphanage within the compartmentalization of the colonial world. Inside the orphanage are the "native" Albanian children who need to be guided to the right path, taught Italian (thus, European) culture and values. Outside the walls are the hopeless colonized subjects and even worse, the dangerous ideas of communism. Even with the terrible conditions within the orphanage, the administration likes to remind the children that the alternative of the street is much worse. But the orphanage's ambiguous position also makes it a viable place for the communist insurgents to make a move. Since the orphans are considered in need of surrogate parents who could be responsible for their socialization, they are made into special targets of the dogmatic propaganda of the fascist regime, something that the communist rebels surely note. This is why both the orphans' literature teacher and Ali seek to turn the children into loyal followers of communist ideals, though not through the violent, humiliating means of orphanage employees, but through appeals to national identity, patriotism, righteousness, and family. Both sides - capitalist colonialists, and communists - have a vested interest in keeping the children off the streets, not out of concern for their well-being, but out of fear that their uncontrolled energy and rage would devolve into violence in service of neither fascism nor communism.

Out in the streets, these orphaned children would really "belong" to no institution and could potentially form an alternative alliance among each other that might challenge the colonizers, but not in ways prescribed by the Communist Party. When the director finally banishes Jaçe and his friends from the orphanage, after they write anti-fascist messages on the very orphanage walls that had separated them from the rest of the city, the boys run out onto the street. This is the same street where Sulo had perished earlier, and so we expect something sinister to happen again. However, the orphans are welcomed by the street children, whose bare feet and lack of shirts lead us to believe that they are even poorer than the orphans. The two groups of children laugh and play together, the children in the street even share some bread with the orphans. This scene, however, cuts abruptly to the next one, where Jaçe and his friends are inside the quarters of the Communist Party. It seems that the transgression into the street will also not be tolerated by the children's new supervisors. Great emphasis is placed on showcasing the communists' quarters in this scene: as a dramatic score plays, the camera pans around the room, focusing one by one on the faces of all present. Among the literature teacher and their friend Ali, the children also find other young men, even some young women and the orphanage's cleaning woman. The communists' quarters are not luxurious, but they bustle with the energy and the exciting feeling that a radical change will come. And for the orphans, the space also promises the sense of inclusion and care they had been missing, and which we are led to believe could not come without subscription to the communist 
ideal. Very didactic in its purpose, the film teaches its viewers of the party's heroic struggle, the nation's historic oppression, and the necessity to follow all party orders. As such, it is not interested in those moments outside when the orphans freely play with the other children - such moments are treated as inconsequential.

Thus, for most of the film's duration, the world outside of the orphanage is forbidden to the children. They are not allowed beyond its walls for long unless they are accompanied by an adult, if they are running an errand, or if they have been invited to have Sunday dinner with one of the families from the city. The outside always presents danger or humiliation - from the taunts that the orphans receive by the "normal" boys who walk the streets confidently next to their parents, to more traumatic events like murder. In fact, when the children leave the confines of the orphanage and "overstep" their limits by abandoning their chaperone, they end up witnessing the first murder in the film. Their friend from the city, Ali, assassinates an Italian fascist in the street where the children are wandering, leading to their questioning by the police in which they deny knowing the man. And of course, it is when Sulo steps over the threshold of the gate that he is killed. The message is clear: do not challenge the spatial divisions of the world constructed around you. Fanon reminds us: "The colonial subject is a man penned in; apartheid is but one method of compartmentalizing the colonial world. The first thing the colonial learns is to remain in his place and not overstep its limits" (Fanon 2004, 15). The apartheid ensured by the orphanage serves to categorize the orphans as something other than the colonizers, as something that needs to be disciplined and trained. At the film's conclusion, this dynamic is reversed when the director is shot as he steps outside the orphanage. Once he makes the first step outside the space of this institution where the colonial apparatus gave him power, the director meets his death at the hands of a communist rebel and the orphans helping him. As predicted by Fanon, the colonized have put an end to the immobility that compartmentalization imposes upon them through use of counterviolence against their oppressors. But, of course, in Lulëkuqet mbi Mure, the orphans are freed from the confines of the orphanage only after they have committed themselves to the communist cause.

\section{Dehumanization and violence in the orphanage}

What is the nature of the violence in the orphanage? It is comprised of the physical and psychological abuse, compartmentalization, and Manicheanism through which the colonizers dehumanize the colonized. Fanon writes:

The colonist is not content with stating that the colonized world has lost its values or worse never possessed any. The "native" is declared impervious to ethics, representing not only the absence of values but also the negation of values. He is, dare we say it, the enemy of values. In other words, absolute evil (Fanon 2004, 6, emphasis mine). 
Were these values seen as absent from the colonial world, there would be hope of rehabilitation. Instead, the colonist constructs the colonial subject as beyond this possibility, as the negation of values. Great effort is needed to carry forward this dehumanization, which serves to ultimately cast the "native" outside the category of the human. Sylvia Wynter points to the Western European colonial expansion into Africa and the Americas as the moment when categorization of people was no longer based on religious modes but secular ones of rationality and reason. The "primary code of difference" became the "cultural-physiognomic variations between peoples" - a racial categorization that placed "natives" in the sub-human sphere of nonrationality (Wynter $1996,477)$. It was during the colonization of the Americas that new identities based on "race" were created and ordered according to skin color, wherein superiority was "premised on the degree of humanity attributed to the identities in question. The 'lighter' one's skin is, the closer to full humanity one is, and vice versa" (Maldonado-Torres 2007, 244). This colonial logic, predicated on the lack of humanity of the people of the colonies, served to support their domination via capitalist exploitation, slavery, serfdom, and genocidal practices. As the defining feature of modernity, such an imperial attitude of suspicion and skepticism of the humanity of those deemed as "barbarian" shaped the world beyond the conquests of the sixteenth century (Maldonado-Torres 2007, 246-7).

Similar skeptical attitudes about the orphans' humanity are at work in Lulëkuqet mbi Mure. The caretaker and the director constantly describe the children as malevolent, unable to think, acting not like people but akin to pests that suck the blood out of the civilized fascist administration. ${ }^{3}$ When the literature teacher tells the director that the children were exhausted after being forced to erase anti-fascist signs on the walls, the director retorts by calling them "deceitful and lazy" and warning the teacher about their trickery. The children are constructed as intrinsically devoid of values: the ways of the civilized are not in their nature as Albanian orphans, so the fascist director needs to educate them. In the discourse of Balkanism, this is a common line of thought - the barbarian and backward people of the Balkans need the guidance of the enlightened westerners in order to enter modernity. Both the director and the caretaker state in clear terms that Albania is benefitting from its occupation by the Italian Empire, which will "improve" the country and finally make it part of "civilization." It is unsurprising that the orphanage

\footnotetext{
${ }^{3}$ This dehumanizing violence starts from the fact that the children lose all signs of personhood when they enter this space - their heads are shaved, and they are made to wear identical uniforms. The shaved heads and uniforms alienate the orphans, who outside of the institution might have passed for children of different social strata. Because they are immediately distinguishable from other, wealthier children, the latter mock them with taunts of "qerosa!" - a word that points out the orphans' bald heads, and to their marginal position in society. Inside the orphanage, their shaved heads and uniforms render them indistinguishable from each other and make their lives interchangeable.
} 
administrators adopt the same rhetoric toward the children and the rhetoric of training the savage, or taming the animal, mirrors the dehumanizing effects of colonialism. This manifests at the level of the colonizer's language via allusions of the colonized subjects' animalistic appearance, movements and gestures, all of which serve to construct the colonized as devoid of humanity and rationality (Fanon 2004, 7).

One scene in the film illuminates these workings of dehumanization. We see the orphanage's accountant at a window, throwing pieces of bread to a group of eager and happy children. He seems to be playing a "game" with them, seeing who can catch the bread with their mouth. The accountant, dressed in a sharp white shirt and black vest that shows the string of his pocket watch, throws pieces of bread to the children. Each child struggles with the others next to him and jumps up to be the one who catches the bread. It is the literature teacher that breaks the activity when he sees what is happening and yells "What is this game?!" The children disperse and the teacher tells the accountant that he is wasting the orphanage's bread. The accountant responds with, "I am making the children more agile. Did you see that Italian circus?" The orphans are so low in the accounts' hierarchy of the human that they can be humiliated and trained as circus animals. Not only that, but the training would be good for them, would teach them "agility" and give their existence worth. The fact that this is an Italian circus is also significant - Italy stands for Europe, and Europe stands for all that is civilized, regardless of the brutality it had caused.

As the children walk away from the game, they complain that the teacher ruined their fun. Jaçe interjects that the teacher was right to stop it. Another boy, Bardhi tells him he is only mad because he was not good at catching. Jaçe's response is a rejection of his own dehumanization: "It's dogs that have bread thrown to them like that, I am not a dog." Taking this as Jaçe's way of calling him a dog, Bardhi becomes angry and the two start a fight in the yard, which causes a great commotion as more children become involved. The caretaker sees this and calls the two boys to his office for their punishment: they must slap one another as he watches. They each give the other a slap, but then Jaçe stops. The caretaker whips Bardhi and orders him to give his friend "five good ones." When it is all over, the caretaker comments on the importance of order and discipline, and to prove his commitment to these ideals, beats Jaçe himself and locks him up in the cellar without any food. This scene reveals that some of children are already knowledgeable of the fact that they are being trained to behave in submissive ways. As one would train or domesticate a dog - through cruel beatings, reprimands and the use of food as incentive to behave - the administrators are training the boys. The accountant's retort to the teacher that he is making the boys more agile is further proof of this 
deliberate effort to dehumanize the children. Combined with the caretaker's punishment of having the boys inflict violence on each other, and thus repeating the gesture of violence until it becomes habit or second nature, the orphanage administrators continue to show the boys what they really think: that these children are impervious to rationality and logic and can only learn through the language of violence and degradation.

The same logic is apparent in the scene where the director expels Jaçe and his close friends from the orphanage. This occurs after Sulo has been killed and the literature teacher has been fired, which had led some of the orphans to retaliate by writing on the walls inside the orphanage, "DOWN WITH FASCISM" and "DOWN WITH THE DIRECTOR." When the director sees these, he storms into the building, grabs Jaçe and two other boys and begins to scream at them to leave the orphanage forever. He bombards them with a slew of insults: vagabonds, bastards, misers, vagrants, criminals, ingrates. He tells them that now they will have to be homeless and ends his diatribe by screaming, "Like dogs you will wander the streets, you will become animals, you'll end up in a ditch!" This insult, which equates the children to dogs is made right before the director banishes the children to the streets, the undisputed compartment of the wretched, uncivilized, colonial subjects who never had the chance to become assimilated into Italian culture. ${ }^{4}$ If the children occupied an ambiguous position regarding their humanity while living in the orphanage, once they are cast outside of it they lose their humanity completely. Under the eye and control of the occupiers, the children's reduction to the state of animal had the protentional to be only temporary. Once they learned Italian and absorbed the fascist ideology, they might have been able to move up to the status that the director, accountant, and caretaker possess as native accomplices of the colonial regime. But because they fail to do this and instead rebel. The children become incorrigible, nothing more than dogs.

We see how the question of the children's humanity and "trainability" comes to light again when the caretaker talks with the orphanage's cook, Loni. ${ }^{5}$ Loni attempts to make the caretaker sensitive to the children's needs, who have been starved for several days:

Cook: They are orphans, this is not right. On one hand, you beat them, and on the other hand you want to deprive them of food. And how much is allocated for them anyway? This little.

\footnotetext{
${ }^{4}$ It is a similar insult that the caretaker yells after Sulo when the boy runs out to the street prior to being shot. He curses him by calling him a son of a dog, or "qen bir qeni."

${ }^{5}$ During this scene, Loni also complains to the caretaker that the accountant and the director have been stealing money from the orphanage and pocketing it, which might be one of the reasons why they let the children go without food for days, and why there are little resources available at the orphanage. The cook mocks their purported patriotism. The caretaker advises Loni to not think about the matter, for they should be grateful for their jobs and the great treatment they are receiving from Italy. Unlike the caretaker, Loni often questions the fascist director, supports the children, and interrupts the Italian music lessons by singing traditional Albanian folk songs.
} 
Caretaker: Ah, but they are bastards. Besides, people need beatings, otherwise they become a problem.

Cook: People can also learn through gentleness.

Caretaker: Yes and no.

Cook: Yes, yes.

The caretaker continues to stress the idea of the children as incorrigible "bastards" who can only learn though violence. But this exchange also reveals that for the orphanage administration, the children are not yet completely outside the category of the human - at times they are indeed people who can be "taught" and at other times are simply irrational, or dogs. Nonetheless, in both cases what is shown by the slippage between the terms used to refer to the orphans is a certain "skepticism" about their humanity, as Maldonado-Torres puts it. Such "misanthropic skepticism" continually questions the humanity of the "barbarians," who are constructed as inferior under the racialization and classification established through colonization (Maldonado-Torres 2007, 246). As such, the orphanage administrators and their Italian fascist overseers find it hard to believe in the humanity of the orphans, whom they see as biologically predetermined to be inferior to them. While the idea that they might be trainable is also present, it is all too easily disturbed by any disobedience on the children's part.

It is disobedience from the children that sets off the chain of events that leads to Sulo's death. When the boy does not follow the caretaker's order to report to his room with the names of the children who had caused his fall, the man becomes furious and forces Sulo out of the boys' room. He does not care about Sulo's continued assertions that he does not know anything about what happened. Sulo calls the caretakers' efforts futile and in an attempt to end this psychological torment, tells him to just "do what [he needs] to do." ${ }^{6}$ This statement sparks even greater rage from the caretaker. By implying that he knows physical punishment is imminent, an expected outcome of the situation and power imbalances between the two, Sulo signals that he knows what the caretaker really is: an instrument at the hands of an empire, a lowly worker in service of the country's colonizers, who try as he might to gain status within the colonial apparatus, will only remain a pawn, frightful only to defenseless orphans. The boy's comment also exposes that the caretaker's method of discipline is violent force. This revelation is nothing shocking, for a large part of the film has consisted of the beatings and humiliation of these children. If the violence was so obvious, why does the caretaker take such offense at Sulo's comment? Why does he feel mocked and ridiculed by the child? I believe this has to do with what underlies Sulo's comment: an understanding of his positionality as an exploited subject and his rejection of this status of inferiority. Sulo and the other children have started to recognize themselves as human,

${ }^{6}$ In the Albanian, Sulo says: “Bëj çfarë ke për të bërë.” All translations are my own. 
not the animals or things the administrators call them. This recognition is a crucial step in the process of liberation, which Fanon names as the process that turns the colonized "thing" into human (Fanon 2004, 2). And it is this recognition and the decolonization that follows it which puts the colonizer's power in jeopardy.

After the comment, the caretaker's questioning of Sulo turns into threats and more violence - he declares he will break the child's neck and drags Sulo down the stairs and out into the yard. Sulo escapes his grip and runs out of the open gate to escape his ire. The caretaker curses him and locks the gate behind him. Pressed closely against one another, the rest of the children watch the scene from their window and start to shout in support of Sulo. They mock the caretaker and, distorting their voices, they call him a fascist and spy. Sulo's complete aloneness and fear outside the orphanage walls is magnified when contrasted with the other children's unified stance against the caretaker, their glee at the insults they hurl and vigor with which they grab furniture to bolt their door shut. The camera focuses on Sulo's concerned face when he hears the fascist patrol round the corner. They yell for him to stop, but Sulo has already run toward the gate's wall and climbed almost all the way up when he is shot in the back and falls, dead. When the other children hear the gunshot, they turn somber and move to the window, whence in unison they yell out Sulo's name. In the process, their bodies become almost one, become even more indistinguishable from one another. Sulo was one of them, and with his shaved head, his plain white shirt and nondescript dark-colored shorts, he could have been any one of the boys.

" $[\mathrm{H}]$ ow do we get from the atmosphere of violence to setting violence in motion? What blows the lid?" asks Fanon (Fanon 2004, 31). In the film, Sulo's murder rests somewhere between what Fanon calls the "trivial incident" that can set off the machine-gunning, and what he identifies as the point of no return occurring once the armed struggle has already started, when the magnitude of violence intensifies (Fanon 2004, 31 \& 47). Sulo's murder happens at a moment when we have been inundated with violence enough to know that it was the only mode of expression their oppressors understand. As Fanon writes, the colonized choose to liberate themselves through violence as a natural result of having been taught it by their colonizers: "The argument chosen by the colonized was conveyed to them by the colonist, and by an ironic twist of fate it is now the colonized who state that it is the colonizer who only understands the language of force." (Fanon 2004, 42). By the time that Sulo is killed, the orphans have not only been beaten by the caretaker, verbally and physically abused by the orphanage director, coerced to labor for the fascists, starved of food, and fought one another, but have also witnessed Ali fatally shooting a fascist in the streets of Tirana and the corresponding agitation caused by this shooting to their occupiers. Thus, they have learned that the legitimacy of their condition rests on violence and force, which also appear to be same tools they need for changing these conditions. I see Sulo's death 
as the point of no return, following Fanon's idea that this is the point when both colonized and colonizers recognize that things cannot continue as usual and a fundamental change needs to take place. Even though the children had known violence before this event, had even used it themselves when they had caused the caretaker's fall down the stairs, it is only after their friend's death that they have no doubt that the orphanage's administration and their fascist rulers are evil, and that they must join forces with the communists who have already taken up the armed struggle.

\section{The revolutionary from the town and the native intellectual}

As has been mentioned, the orphans join the struggle for liberation thanks to the guidance of two key figures who are part of the communist insurgency: Jaçe's friend Ali and their literature teacher Luan. ${ }^{7}$ I read these characters as an iteration of what Fanon calls the "revolutionaries from the towns", who have been ostracized from the native parties for their radical views and angry outbursts (Fanon 2004, 28-9). He writes that "these undesirables with their inflammatory attitude [...] realize in a kind of intoxication that the peasant masses latch on to their every word and do not hesitate to ask them the question for which they are not prepared: 'When do we start?'” (Fanon 2004, 29). Ali, as well as the literature teacher, have a similar relationship with the children. The boys hang on every word these two men say and much of what the children do is aimed at pleasing both Ali and the teacher. Before the culminating action of helping to kill the fascist director, the children act together to carry out a series of minor subversions: they steal a communist leaflet and spread the information on it to each other, they disobey and mock the orphanage administration, they set up a trap that makes the orphanage's caretaker break his arm, they refuse to spy on each other, instead they spy on the fascists and report back to Ali and the teacher. They always seem to be asking "when do we start?", though their zeal is quieted and monitored by Ali and the teacher. Fanon warns against the native elite of colonial countries, whose goal is not to dismantle the system, because they have learned how to use it to their advantage. For them the greatest threat is not the colonizers but the potential of mass mobilization of the peasantry (Fanon 2004, 28). I do not think that the characters of the teacher and of Ali are concerned with this, as they are both obviously fighting to end the Italian occupation. However, in guiding the children in the "proper" uses of violence, they start to control the

\footnotetext{
${ }^{7}$ Ali is sometimes also referred to by Jaçe as his neighbor, something that implies Jaçe might not actually be an orphan, but a boy placed there by parents who cannot afford to feed him. It is interesting that Jaçe is one of the most important characters of the film, who becomes somewhat of a leader among the orphans. While his exact situation is not revealed, Jaçe's position gives him access to his "neighbor" Ali and brings him closer to a normative family than the other children. It is as if the filmmaker could not allow for a true wretch or bastard, to be the leader of the orphans' rebellion.
} 
revolutionary power that these children hold. It is not a huge leap to imagine why this theme of patient guiding by their elders might have been a theme in the film - it is the Party telling viewers in the 1970s to listen and not disobey.

There is a telling exchange between Ali and Jaçe that reveals the discipline required by the Party. This occurs the day after the caretaker falls and breaks his arm. Fed up by the abuse they experience in the orphanage, and inspired by communist leaflets, the language teacher's lessons, and Ali's shooting of an Italian fascist, the children devise a way to get back at the caretaker. At night, they plant a string by the top of the stairs that the caretaker does not notice when he is walking downstairs. His fall and injury, however, are not considered as simple child's play by the fascist administrators of the orphanage. They immediately interpret it as an act influenced by communist anti-fascist sentiment and punish the children by depriving them of food and tormenting them with verbal abuse. During this time, Ali comes to visit Jaçe and they meet by the gate of the orphanage. Their exchange begins with Jaçe saying to Ali that he knows he is a communist, because he has seen him shoot the Italian man. Then, Jaçe announces that the children carried out an action of their own. Ali laughs at him, considering the action not very significant. Nonetheless, he cautions:

Ali: Wait, what if he had broken his neck?

Jaçe: That's what we wanted.

Ali: Oh, really? What do you think this is, we just go in the streets and shoot?

Dangerous spies are killed but only when the party says so.

Jaçe: But he is a spy.

Ali: Sure, sure, but these things have an order.

Jaçe: But because of this we have been starved all day.

Ali: Ah, here you go, I almost forgot. [Ali gives him a sandwich that Jaçe considers but then says he will eat later.]

Jaçe: That's not why I told you this.

Ali: Okay, okay. Are you upset?

Jaçe: We just wanted to do something like what you did.

Ali: But you had a duty, or have you forgotten it?

Jaçe: Yes, but the man has not come. We always keep watch.

Ali: Anyway, good job, because these things take courage. But for anything new, you have to ask, do you understand?

Jaçe: Yes.

Ali: Good. There needs to be discipline. [Notices Jaçe looks annoyed.] What, you don't like it?

Jaçe: Those are the words the caretaker tells us every day.

Ali: Well, you shouldn't have gotten yourself in this situation, then. You might have as well told them that the murderer was Ali Hima, your neighbor.

Offended by Ali's joking, Jaçe grabs his friend and tries to hit him in the face. Ali calms him down and laughing, tells him to stop because he "[hasn't] even eaten, [he has] no energy." It is evident from this scene that the communists consider revolutionary violence as something that needs to be planned, 
deliberate, and not to be determined by the explosive emotions of the orphans. Jaçe's comment equating Ali's disciplinary tone to that of the caretaker shows the boy's understanding of the nature of this reprimand. It is also interesting to note the parallel movement that the caretaker and Ali take when they are speaking with Sulo and Jaçe, respectively. As they are talking, Ali offers Jaçe a sandwich, meanwhile the caretaker attempts to bribe Sulo into confessing who had caused his injury by offering him a bowl of soup and some bread. Both boys have been without meals and are starving at this point, yet neither of them accepts the food, Sulo says he is sick, while Jaçe makes a vague statement that he will eat it later. Sulo's gesture is clearly the film's way of showing his loyalty to his friends, but Jaçe's gesture is more complicated. He considers eating the food, even brings it up to his mouth, but then stops. It is as if the children are seeing through the words of these adults and finding their own small ways of resisting. In this case, it is through the refusal of this gesture of "kindness" and by making up excuses for doing so (which are ones that would not outright offend either man), that the children can assert their own agency.

Nonetheless, Ali (and as we will see, the teacher) is able to control the children through a careful harnessing, monitoring, and directing of their nascent rage and violence. Jaçe is right to point out how the emphasis on discipline and order reproduces the dynamics of the orphanage, which, in addition to a foundation of violence, are also dependent on ideals of "reason" and "objectivity." To this, Fanon says, "[f]or the colonized subject, objectivity is always directed against him" (Fanon 2004, 37). In the case of the film, the native intellectual and the revolutionary from the town, while engaged in the violent struggle, nonetheless "are not sure that this reckless violence is the most effective way of defending their own interests" (Fanon 2004, 25). Their problem is with the unregulated violence of the children, enacted within the space of the orphanage and thus, away from the watchful eye of the party. Ali's words serve to curb the children's actions, for although Jaçe recognizes the hypocrisy of Ali's words and is clearly upset about them, he still deeply respects and admires the older boy. And again, it is interesting to note here that the caretaker employs the same strategy of appealing to reason and objectivity when he petitions the children to confess who hurt him. Whether on purpose or not, the film creates these multiple parallels between the caretaker and Ali's actions.

While Ali is able to influence the children during his visits to the orphanage, the literature teacher, Luan, has the children's attention within the orphanage during their daily lessons. Unlike Ali, Luan is not seen carrying out violent acts himself - his tools are different, they are words and poetry. This figure of the revolutionary teacher that spreads word of the party is popular among Albanian cinema of the ' 60 s and '70s. Scholars have attributed this to a possible allusion to Enver Hoxha, who had been a schoolteacher himself (Peshkopia, Zahaj, Hysi 2014, 76). Such characterization of Hoxha was often made through the progressive teacher from the city, who educated and enlightened 
the peasants of the countryside, an archetype that again recalls Fanon's conceptualization of the "native intellectual." Furthermore, it is no coincidence that this is a teacher of literature for as Fanon points out, it is important for the colonized to reclaim their own cultural productions and national identity in response to the forceful imposition of the colonizer's culture and values. In the case of Lulëkuqet mbi Mure, the literature teacher makes deliberate choices about the works he reads to the orphans. He is careful to only cite key figures of the Albanian nationalist movement of the $19^{\text {th }}$ century - the Albanian National Awakening, which sought independence from the Ottoman Empire and the creation of the Albanian nation. The literary works he reads to the children espouse clear nationalist ideology, where the suffering of the Albanian people under Ottoman rule is used to make a call for national unity and, in turn, for homogeneity of identity and political convictions. Further, by invoking figures of the National Awakening, the teacher makes an explicit connection between historical subjugation and the current struggle for liberation from fascist Italy. Thus, literature serves as an effective strategy for the indoctrination of the children into the Communist Party, especially due to its strong appeal to emotion and group (and national) belonging.

We first meet the teacher after the children are forced to stay up all night to erase anti-fascists messages written on the walls surrounding the orphanage. As the children walk back to the orphanage in the morning, tired and covered in paint, the teacher runs into them. Finding out what they had been doing in the night leads the teacher to read aloud to them a poem by Naim Frashëri, one of the leading figures of the Albanian National Awakening movement. Frashëri's works are dedicated to the national ideal, and in fact, played a key role in constructing the idea of Albania at the time when it first emerged as a nation-state after a long Ottoman rule. The poem, titled "Tradhëtorët" / "Traitors", begins with a call for listeners to beware of the traitors among them, then addresses these traitors directly, telling them they will regret betraying the nation. Reading this warning to the children who had acted against the interests of the national liberations struggle, achieves the teacher's desired effect - from that point on, the boys are motivated to prove to him that they are not traitors. This accounts for many of the actions that the children take, like collaborating with Ali to spy on the director or hiding and distributing the communist leaflets. For his own part, the teacher stands up on behalf of the children in meetings with the director, bringing up the "inhumane methods" that the director employs and mocking the "humanism" of Rome, which makes him a target of the director's ire. The director sends a spy to follow him, accuses him of being a communist and eventually fires him, but not before the teacher gives a moving speech at the climax of the film. This occurs right after Sulo has been shot, when the children are at their most vulnerable. The teacher enters the classroom to find the children silent, a bouquet of flowers on Sulo's seat. He asks Jaçe to read a poem aloud "Anës Lumenjve" / "Next to the Rivers," by Fan Noli (who had been an ardent 
enemy of the fascists and King Zogu's rule). When the boy stumbles through the words, the teacher takes over and recites the poem from memory. He is overcome with emotion as he recites, his voice grows louder and his gestures wilder. Written in 1928, the poem lists the ways in which the Albanian people have been oppressed and subjugated throughout history, from the Ottoman occupation to WWI. The end of the poem turns into a revolutionary call for peasants and workers to revolt, in the same way that the rivers overflow and flood the land. After reciting the poem, the teacher delivers this speech to the boys, who have been watching him intently:

An orphan country is unlucky. They take advantage of it. They deny its ancestors and origin; they deprive it of its language and daily bread. They abuse it and spit on it, they take away its dignity. Who will save it? It will save itself. It will tell its sons, stand before me: here is my anger in your hands like a sword, let us accomplish this work. ${ }^{8}$ And from this moment, the country is no longer orphaned. And you are no longer orphans. A mother struggles for you, a mother who is always near. ... Listen to her, lest you want to be taken advantage of, to be treated like dirt, to be killed, and to be deprived of honor.

In this speech, the teacher captures the essence of colonial exploitation and dehumanization, and offers the children a way out of their state of despair. First, he notes the manners in which an "orphan" country or people can be abused - through denial of its culture, history, language, and bread. Then, he presents them with a way out through harnessing the power of their anger and by taking up arms. This moment the teacher speaks of is the moment when the atmosphere of violence - that constant state of violent existence that the colonizers have created and that allowed for the establishment of their power - leads to a response of armed struggle for liberation. And yet, it is obvious that the teacher's speech serves a similar function to Ali's talks with Jaçe. The teacher seizes the moment, using the children's vulnerable states and their sadness at the death of Sulo to earn their loyalty. Certainly, the communist efforts to liberate the country were warranted, but we must question the ways in which Ali and the teacher simultaneously incite and curb the children's feelings.

The teacher equates the colonized country to an orphan, wherein the orphan is imagined as the most unfortunate member of a society, a disposable body that can be abused without impunity, as the film has indeed shown. But the orphan, here, is also imagined as the child missing a mother - it is the mother that makes a child orphaned, because it is the mother whose "natural" duty is to care for the children. That the father is also missing seems to not even be taken into consideration. It is by invoking the figure of the moth-

\footnotetext{
8 This language of labor mirrors Fanon's own words: "For the colonized, this violence represents the absolute praxis. The militant therefore is one who works. The questions the organization asks the militant bear the mark of this vision of things: 'Where have you worked? With whom? What have you accomplished?' The group requires each individual to have performed an irreversible act" (44).
} 
er that the teacher can earn the children's greatest commitment. And this comes as no surprise, knowing how essential tropes of motherhood are to nation-building. The promise of a mother that can care and struggle for them on a most fundamental level proves irresistible to the children, who throughout the film have cemented allegiances among each other by swearing on their "mother's soul." The literature teacher is well aware of the strong effect such an appeal to family and a mother's care has on the orphaned children, which is why he also employs it later when he talks about the Communist Party. After this passionate speech, the children are moved to organize themselves and write anti-fascist messages on the walls, then join the teacher and Ali in the communist quarters. During the film's ending scenes, Jaçe and another boy help one of the communists shoot the director. As this man shoots the director, he utters the final words of the film: "In the name of the people, you are sentenced to death!"9 The director falls to his death at the orphanage's gate, which had helped to compartmentalize the children's lives and separate them from the rest of the city. Through this act, the orphans finally become part of "the people" who were struggling for liberation.

\section{Conclusion: the children's alternative}

After the director is shot, Jaçe flees the scene. The film ends with him pedaling through town, now seemingly free and saved from the violent world of the orphanage. We are meant to believe that Jaçe is no longer an orphan now that he is part of the Communist Party and the national liberation struggle. Not only has he shed that identity, but he cannot even re-enter the orphanage, for he has performed the "irreversible act" that now places him into the ranks of the militants (Fanon 2004, 44). His participation in this act of violence has made a new "man" out of him, a man of the revolution. Is this similar to the new humanism envisioned by Fanon, which would lead to a "new rhythm, specific to a new generation of men, with a new language and a new humanity" (Fanon 2004, 2)? At the core of Fanon's new humanism is the recognition of the humanity of all those who colonialism had cast outside the category of the "human" and the end of their subjugation. Homi K. Bhabha, in the forward to The Wretched of the Earth's 2004 edition, links Fanon's ideas of a new humanism with his stance against the imposition of what seemed as an unequivocal choice that Third World countries had to make after gaining independence: the choice between socialism or capitalism (Bhabha 2004, xvixvii). Rather than being limited to only these two choices, Fanon calls for postcolonial countries to focus on values, methods, and styles that are specific to them (Fanon 2004, 55). And while he identifies the need for a redistribution of wealth the most critical issue of the time, Fanon's vision of a hopeful new humanism, without any compartmentalization and subjugation, also goes

\footnotetext{
${ }^{9}$ In the Albanian, the sentence spoken is: "Në emër të popullit jeni dënuar me vdekje!”
} 
hand in hand with the "destruction of the Manichaeanism of the cold war" (Bhabha 2004, xiv).

In Lulëkuqet mbi Mure, the overt ideological purpose of the film leaves little room for any possibilities outside of this cold war dichotomy. As a result, what we find is a lesson about the perils of capitalism and the necessity of adhering to the principles of socialism. Only two choices are offered by the film: you are either a fascist and capitalist, colonizer and colonial bourgeoisie, or you are a communist, a revolted colonized subject ready to take up arms for national liberation and to fully subscribe to state socialism. No other alternative to fascism is imaginable and the film implies that a total allegiance to the Party is necessary lest the foreign threat prevail again. As we have seen, the orphans' ambiguous position in the colonial system makes their choice a crucial one, which is why their actions in the film get progressively more rebellious toward the orphanage administration as their education from the communist insurgents intensifies. Very little attention is given to the children's own thinking or agency, to the possibility that they might be able to forge something different. It is only through careful attention to the children's small modes of resistance and solidarity unmediated by the Party, that we can observe a gesture toward an alternative, even though this alternative ultimately remains unrealized.

I would like to conclude by considering these unrealized alternatives that the children created on their own. The orphans overtly resisted the fascist administration: they insulted the orphanage administrators and called them fascists, got revenge on the children who taunted them in the streets (for instance, by writing "spy" on the back of one of them), stole and read partisan leaflets, even engineered a way to injure the caretaker. They also resisted through refusal: refusal to sing Italian songs, refusal to properly pronounce Italian words during their language lessons, refusal to spy or physically harm each other, refusal to reveal Ali's identity to the fascist police, refusal even of food offered to them with too many strings attached. Yet another form of their subversion is their mocking and parodying of the orphanage administrators, especially of the caretaker. For instance, the children mimic the meltdown he experienced when the music teacher stormed out, too fed up with the children's choir. With a make-shift hat fashioned to resemble that of the teacher's, the children recreate the scene in their sleeping room during the night, with one child pretending to be the teacher, and another pretending to be the caretaker. The "caretaker" makes exaggerated gestures and pleas for the "teacher" to stay, allowing the children to expose the caretaker's weakness and pathetic sycophancy toward anyone higher than him in the social ladder. This performance ends with a mock shooting of "the caretaker," before Jaçe and his close friends retreat to their corner of the room to plan their trap on the real caretaker.

These subversions would not have been possible without the solidarity that the orphans have built with one another, and which has ensured their 
survival in the miserly conditions of the orphanage. When Jaçe is locked up in the cellar after refusing to hit Bardhi, the other children stealthily stow away pieces of bread from their meals so they can sneak it into him. Later, the children band together to get Jaçe and Bardhi to make up after their fight. Jaçe starts to come around after Ali also advises him in a similar fashion. When he relates Ali's advice to the others, one of the children responds, "So what if Ali told you? What about us, who are your friends?" This statement is telling of the fact that despite their subjugation, the children place worth on their own convictions and actions, and see great importance in the friendship among one another. In fact, through their friendship, the children create links of solidarity that are not based on national identity. While the communists' initiation of the orphans into their party is based on a specific idea of the nation as an oppressed and colonized entity, the children develop ways of coming together and to each other's rescue that do not depend on their unity as Albanians. In fact, it is the literature teacher who gives them cultural references for what makes them part of the Albanian nation, and it is the partisan leaflets they steal or obtain from Ali that teach them about the national struggle, which they learn is taking place throughout the country. The communists are invested in giving the children a new identity, one where they are not labeled as orphans but as children of Albania.

The children, however, do not see as completely insignificant an identity that has made possible their friendship, solidarity, and endurance. Together, they have learned to use their position as orphans strategically to survive among the violence that surrounds them. When an officer approaches them after they witness the shooting of the fascist in the street, he asks them if they knew who fired the shot. "We are from the orphanage, we do not know anyone," the children respond. Of course, they had all recognized the shooter had been Ali, but the knowledge of their position as orphans is used intentionally to feign ignorance. How could they know who fired the shot, when they are orphans stuck inside the walls of the orphanage? Once again, the children demonstrate knowledge of their positionality and an ability to use that knowledge to subvert the colonial fascist system. However, the film's didactic, ideological purposes do not allow their subversion to develop on its own, and the alternatives that the children could have created remains unfulfilled. Instead, Lulëkuqet mbi Mure confronts the viewer with "the unequivocal choice between socialism and capitalism" and in doing so, limits its own imagination for a new humanism and a more radically different future (Fanon 2004, 55).

Bhabha, Homi K. 2004. "Foreword: Framing Fanon." The Wretched of the Earth. Trans. from the French by Richard Philcox; introductions by Jean-Paul Sartre and Homi K. Bhabha, vii-xiii. New York: Grove Press.

Bobi, Gabi. 1994. Konteksti i Vetëkulturës [Context of Self-Culture]. Peja: Dukagjini. 
Fanon, Frantz. 2004. "On Violence." The Wretched of the Earth. Trans. from the French by Richard Philcox; introductions by Jean-Paul Sartre and Homi K. Bhabha, 1-63. New York: Grove Press.

Gjikaj, Eldon and Artan Puto. 2008. "Kinematografia Shqiptare Midis Nostalgjisë, Groteskut dhe të Ardhmes: Një Histori e Treguar nga Kineastet [Albanian Cinematography Through Nostalgia, the Grotesque and the Future: A Story Told by the Filmmakers]." Përpjekja, XIII (25, Fall): 6-28.

Hom, Stephanie Malia. 2012. "Empires of tourism: travel and rhetoric in Italian colonial Libya and Albania, 1911-1943." Journal of Tourism History, 4 (3): 281-300.

Juka, Gëzim. 2012. Shteti Shqiptar dhe Shkodra - 1912-2012. [The Albanian State and Shkodra - 1912-2012]. Shkoder: Rozafa.

Kallis, Aristotle. 2000. Fascist Ideology: Territory and Expansionism in Italy and Germany, 1922-1945. London: Routledge.

Lulëkuqet mbi Mure [Red Poppies on Walls]. 1976. Directed by Dhimitër Anagnosti. Screenplay by Petraq Qafzezi. Tirana: Kinostudio Shqipëria e Re.

Maldonado-Torres, Nelson. 2007. "On the Coloniality of Being." Cultural Studies, 21 (2-3): 240-270.

Mclaughlin, Paul. 2014. Radicalism: A Philosophical Study. New York: Palgrave Macmillan.

Mëhilli, Elidor. 2018. "Globalized Socialism, Nationalized Time: Soviet Films, Albanian Subjects, and Chinese Audiences across the Sino-Soviet Split." Slavic Review: 77 (3): 611-637.

Peshkopia, R. \& S. Zahaj, \& G. Hysi. 2014. "The Myth of Enver Hoxha in the Albanian Cinema of Socialist Realism: An Inquiry into the Psychoanalytical Features of the Myth." Framework: The Journal of Cinema and Media, 55 (1): 66-82.

Todorova, Maria. 2010. Imagining the Balkans. New York: Oxford University Press.

Williams, Bruce. 2012. "Red Shift: New Albanian Cinema and Its Dialogue with the Old." A Companion to Eastern European Cinemas, ed. by Anikó Imre, 224-243. Chichester, West Sussex: Wiley-Blackwell.

Wynter, Sylvia. 1996. "Beyond Miranda's Meanings: Un/Silencing the 'Demonic Ground' of Caliban's 'Women." The Routledge Reader in Caribbean Literature, eds. Allison Donnell and Sarah Lawson Welsh, 381-385. London and New York: Routledge. 